\title{
DISERTACIONES
}

Grupos minoritarios y estigmatizados: diversidad funcional, religiosa, étnica, afectivo-sexual o de identidad de

\section{LA IDENTIDAD MEDIÁTICA DE FRANCISCO DE ASÍS DE BORBÓN}

\author{
Francisco de Asís de Borbón’s Identity Constructed by the Media
}

\section{A identidade midiática de Francisco de Assis de Bourbon}

Félix Colás Loricera, Universidad de Deusto (España)

felix.colas@opendeusto.es

Recibido: 11 de enero del 2021

Aprobado: 9 de marzo del 2021

Fecha de prepublicación: 6 de agosto del 2021

\section{RESUMEN}

Los medios de comunicación representan imágenes, entre ellas, las del colectivo LGTBQ que pueden perdurar en el imaginario social y forjar los procesos de creación de identidades personales. La participación de Francisco de Asís de Borbón en la publicación periodística Los Borbones en pelota siguió las líneas de representación de las masculinidades disidentes del siglo xix. El rey es visible en 36 de las 102 imágenes que conforman la colección. El propósito de este artículo es trazar líneas de conexión entre las representaciones presentes en las viñetas, la disidencia de género de Francisco y las publicaciones divulgativas y académicas actuales sobre su vida. Para esto, se ha trabajado con las 36 imágenes en un análisis que aúna fuentes primarias y secundarias relativas a la biografía de Francisco de Asís, en un marco metodológico-teórico queery el análisis de contenidos. Como conclusión, se infiere que las viñetas fomentaron estereotipos que marcaron la biografía de Francisco, incluso en publicaciones recientes. A pesar de los cambiantes contextos y voluntades, se mantienen ideas contradictorias y cierto desconocimiento general como marcadores de la identidad mediática del rey consorte, lo que hace necesario y enriquecedor traer estos perfiles al centro del análisis.

Palabras clave: monarquía; comunicación; LGBTQ; masculinidad. 


\section{DISERTACIONES}

Grupos minoritarios y estigmatizados: diversidad funcional, religiosa, étnica, afectivo-sexual o de identidad de género en la comunicación

\section{ABSTRACT}

The mass media represents images of the Lesbian, Gay, Bisexual, Transsexual, and Queer (LGBTQ) community that persists in the social imagination over time, and therefore shapes the processes involved in the development of personal identities. Francisco de Asís de Borbón's presence in the satirical print Los Borbones en pelota represented dissenting masculinities from the 19th century. The king is present in 36 out of the 102 pictures that make up this collection. The hypothesis states that it is possible to draw parallels between the representations in the strips, Francisco's gender dissidence, and the current informational and academic publications about his life. The 36 pictures have been analyzed for the purposes of combining primary and secondary sources concerning Francisco de Asís' biography, marked by a "queer" methodological-theoretical framework and content analysis. To conclude, it can be inferred that the strips encouraged stereotypes that were part of Francisco's biography, even in more recent publications. Despite the changing contexts and wills; conflicting ideas and a certain degree of general ignorance persist as markers of the king consort's identity constructed by the media, making it necessary and rewarding to carry out analyses focusing on these profiles.

Keywords: Monarchy; communication; LGBTQ; masculinity.

\section{RESUMO}

As mídias representam imagens do coletivo LGBTQ que podem persistir por muito tempo no imaginário social e forjar os processos de criação de identidades pessoais. A participação de Francisco de Assis de Bourbon na publicação jornalística Los Borbones en Pelota seguiu as linhas de representação das masculinidades dissidentes do século xix. O rei é visível em 36 imagens das 102 que compõem a coleção. A hipótese é que se traçam linhas de ligação entre as representações presentes nas vinhetas, a dissidência de gênero de Francisco e as publicações informativas e acadêmicas atuais sobre sua vida. Trabalhamos com as 36 imagens numa análise que combina fontes primárias e secundárias relacionadas com a biografia de Francisco de Assis, e que é marcada pelo referencial teórico-metodológico queer e pela análise de conteúdo. Como conclusão, infere-se que as vinhetas fomentaram estereótipos que marcaram a biografia de Francisco mesmo em publicações recentes. Apesar da mudança de contextos e vontades, ideias contraditórias e um certo desconhecimento geral permanecem como marcadores da identidade midiática do rei consorte, o que torna necessário e enriquecedor trazer esses perfis para o centro da análise.

Palavras-chave: monarquia; comunicação; LGBTQ; masculinidade. 


\section{DISERTACIONES}

ESTUDIOS

\section{Introducción}

El presente estudio se centra en el análisis de la identidad mediática de Francisco de Asís de Borbón, con especial atención a la publicación Los Borbones en pelota. Francisco de Asís vivió entre 1822 y 1902 -y la publicación fue realizada en 1868-, lo que sitúa este análisis en dos contextos históricos: la etapa isabelina como contexto general, entendida de manera amplia, y la Revolución "La Gloriosa”.

El periodo isabelino es generalmente entendido como aquel que se desarrolla desde la muerte de Fernando VII en 1833, hasta la Revolución en 1868. Sin embargo, las implicaciones y características propias de este periodo fueron visibles hasta la irrupción de la Guerra Civil (1936-1939). Esta época estuvo marcada por la apertura de frentes, uno de los más citados es el de la España liberal frente a la conservadora -división que culminaría en una Guerra Civil (Zubiaurre, 2014) - y por el desarrollo económico e industrial que formó la identidad burguesa. Así mismo, una de las consecuencias de estos dos factores fue la Revolución de 1868, precedida por numerosos intentos previos de eliminación del sistema borbónico. Después de esto, comenzó un periodo de "ensayo y error" en el sistema de organización gubernamental español, conocido como el Sexenio Democrático (1868-1874) que incluyó una regencia, la Primera República y una monarquía electa.

La diversidad sexual y de género se vio afectada por este contexto, y en esa línea, el caso del rey consorte es particularmente paradigmático, rico en información y poco estudiado. Nacido en Aranjuez en 1822 fue el segundo de los hijos del infante Francisco de Paula de Borbón y Luisa Carlota de Borbón-Dos Sicilias. Tras una juventud en la que se formó en el extranjero y posteriormente en Pamplona como coronel de caballería, fue elegido para casarse con su prima Isabel y convertirse en rey. Su vida en este cargo se desarrolló entre 1846 y 1868, año en el que la Revolución "La Gloriosa" forzó a la familia real al exilio. Una vez en Francia, lejos de la presión del trono, la pareja real se separó y Francisco adquirió un palacete en las afueras de París, en el que pasó el resto de su vida hasta su muerte en 1902. Su biografía está marcada por la disidencia de género en diferentes niveles que se explican en los apartados sucesivos.

Cuando el rey tenía 46 años, algunos meses después de la Revolución, protagonizó junto con otros miembros de la corte una publicación de gran impacto, una colección de viñetas satíricas cuya autoría se adscribe a Gustavo Adolfo y Valeriano Bécquer. La firma que figura es SEM, unas siglas bajo las cuales se publicaron viñetas que tuvieron valor histórico, centrado en la expansión de valores antiborbónicos. Tienen un contenido mayormente pornográficojocoso, cuyo objetivo es criticar el sistema borbónico y justificar la irrupción del Sexenio Democrático. Las viñetas estaban destinadas a un periódico del mismo perfil, llamado Gil Blas; un ejemplo de periodismo en "prosa castiza, dialectal, faltona, divertida, académica y de mala leche" como comentaba Fernández Jiménez sobre Campmany $(2021$, p. 6). Es una cuestión que ha sido estudiada en ocasiones anteriores y a la cual se añaden, en este caso, las cuestiones relativas al género y a la sexualidad. Su estudio, por tanto, contribuye al conocimiento de los modos y tipologías de la comunicación tradicional española y de la sociedad que esta representa, especialmente en lo que concierne al colectivo LGTBQ.

Como afirman Boos de Quadros, Durieux, Foletto y De Souza en la revista Disertaciones: "Las personas buscan y usan información constantemente como parte de su vida diaria. Informaciones relacionadas con el trabajo, el ocio, la salud, el dinero, el clima, la familia, productos y servicios son puestas a disposición desde 


\section{DISERTACIONES}

ESTUDIOS

múltiples fuentes" (2021, p. 3). En este caso, las viñetas formaron parte de un microuniverso de fuentes, ya que se acompañaron con coplas, imágenes, su consecuente teatralización y el boca a boca. Además, en un primer momento formaban parte de las informaciones relacionadas con el ocio. Sin embargo, sus raíces fueron más profundas porque eran reflejos de las percepciones que los hombres con masculinidades disidentes generaban en la sociedad. A su vez, las imágenes creadas en diferentes medios sobre la disidencia de género del rey, contribuyeron a la generación de estereotipos, que, como se analizará en este artículo, perduraron no solo en la identidad del protagonista, sino también en la de otros hombres en situaciones similares, y, sobre todo, en las publicaciones historiográficas y mediáticas relacionadas.

Con la finalidad de conocer esos estereotipos, se crearán campos semánticos y asociaciones entre las representaciones visuales de las viñetas y la propia identidad del sujeto. Así, a través de y gracias a la teoría queer, se consigue situar al rey consorte como centro de una investigación y analizar cómo a lo largo de los años se le ha asignado un papel secundario. Las viñetas son un elemento histórico relevante, ya que crearon y fijaron representaciones en el imaginario colectivo durante mucho tiempo gracias al poder visual e incluso auditivo que estas generan. Contribuyeron, por ejemplo, a la divulgación de la idea de que Isabel ॥ era "la reina ninfómana", como explica Burdiel (2012), también extendieron ideas que consideraban amoral la política isabelina. Ahora, sirven como material de análisis para conocer la representación de predecesores de los colectivos LGTQQ $^{1}$ en la comunicación a lo largo de la historia. La fuerza que tiene la asociación "Isabel II - reina ninfómana” en el imaginario colectivo, no es menor a la que tiene "Francisco de Asís - rey afeminado"; sin embargo, esta segunda ha sido relegada a papeles secundarios en publicaciones anteriores.

\section{Estado de la cuestión}

Los Borbones en pelota es una publicación cuya relación con la identidad del sujeto es muy directa. Las viñetas ofrecen varias imágenes con mensajes contundentes y ricas en información. En ocasiones vienen acompañadas de coplas cortas y crean formas de comunicación efectivas, que consiguen mensajes virales, simplificados, cortos y duraderos, similares a las redes sociales en la actualidad. Esta abundancia y relevancia de información ha hecho que otros autores estudien esta serie, centrándose en dos aspectos: por un lado, la autoría (Pageard et al., 1991), representando esta un caso único en la carrera de un reconocido poeta español y de su hermano; y por otro, la relevancia política, especialmente en lo que concierne a la figura de la soberana, Isabel ॥ (Burdiel, 2010). En este caso se desplaza el foco analítico hacia un personaje que, por su condición, ha sido permanentemente relegado a papeles secundarios a pesar de ser una figura con basta información y representativa de su época y grupo social, en cierto grado.

Además del estudio de Burdiel sobre la figura de Isabel ॥ y su corporalidad en las viñetas, existen otros antecedentes que de manera similar complementan este estudio. En 1995, Vidal Sales publicó la única biografía de Francisco de Asís, que al día de hoy necesita actualizarse a la luz de nuevas metodologías y teorías. Vidal Sales no es, sin embargo, la única fuente de información sobre la identidad del rey, ya que existen documentos en varios fondos como el Archivo del Palacio Real, el Archivo Histórico de Protocolos de Madrid, el Archivo Histórico Nacional y

1 Lesbian, Gay, Bisexual, Transexual, Queer. 


\section{DISERTACIONES}

ESTUDIOS

el Archivo Municipal de Épinay-sur-Seine. Así mismo, otros autores han escrito de manera secundaria sobre su vida, como la propia Burdiel en la biografía de Isabel ॥ (2010), Pedro de Répide (1932) en una de las primeras biografías de la reina y, Eusebio Ferrer Hortet y María Teresa Puga García en Se busca Rey consorte (1993). También existe un amplia base teórica con autores como Judith Butler o Francisco Vázquez, que permite el desarrollo de nuevas investigaciones, ya que ninguno de los trabajos mencionados trata directamente de la identidad del rey en su masculinidad disidente y su representación en los medios de comunicación, ni mucho menos desde una perspectiva queer.

\section{Metodología}

Los estudios sobre las identidades disidentes y su representación en medios académicos y divulgativos son necesarios porque el campo teórico-metodológico de la historiografía se enfrenta en la actualidad a debates sobre la profundidad de sus raíces discriminatorias, especialmente, sobre la relevancia que estas tienen en la generación de conocimiento histórico. Durante años, académicos y activistas han intentado acercar este campo a la transversalidad e inclusividad que han de caracterizar a todas las ciencias del siglo xxı. Para ello, se han construido marcos teóricos que fundamentan la importancia de la perspectiva queer y las condiciones en las que esta se ha de integrar en los procesos de desarrollo de conocimiento. Puesto que la propuesta es una investigación histórico-comunicativa centrada en formatos de representación de una identidad disidente, la carga teórica en lo que respecta al marco queer no hace sino aumentar.

La formación de identidades queer como la del rey consorte, es frecuentemente asignada en términos de responsabilidad a agentes externos, incluyendo su categorización (Foucault, 1977), procesos médico-psiquiátricos y legales (Cleminson \& Vázquez García, 2011) y en ocasiones religiosos o políticos. Autores como Cleminson y Vázquez (2011) y Cruz Valenciano (2014) coinciden en la relevancia de la moral victoriana decimonónica como motor del gran cambio en la percepción de los homosexuales. Las investigaciones biográficas y de cuestiones relacionadas con su comunicación, también aportan información respecto a la evolución desde el modelo de fusión entre sexualidad y manifestaciones de género hacia el modelo de separación entre orientación sexual e identificación de género. Este cambio, a su vez, fue fruto del siglo xix y, como Oscar Guasch explica tiene valor teórico para la historiografía queer, en cuanto el investigador se ha de localizar en uno u otro modelo, no solo teniendo en cuenta el marco cronológico, sino también geográfico y personal del personaje estudiado:

\section{Existió en España un modelo "pregay" cuyos representantes no eran conscientes de ellos mismos como encarnando una categoría separada de seres humanos. Las dos figuras que popularizaron este modelo fueron el "marica" (afeminado) específicamente español, y el "maricón” (homosexual activo). Es decir, no se trataba de homosexuales, sino de tipos que eran diferenciados por su inclinación hacia el rol activo o pasivo y por su grado de afeminamiento, y que fueron usados por el mundo heterosexual para fijar los límites entre masculinidades aceptables y no aceptables. (Cleminson \& Vázquez García, 2011, pp.12-13)}

En el caso que ocupa esta investigación, Francisco de Asís, se emplaza cronológicamente en el modelo de indistinción entre orientación sexual e identificación de género. Por tanto, se encuentra en la noción de sujeto "pregay" propia del siglo xix que explicaban Cleminson y Vázquez García (2011, pp. 12-13). Introducir este concepto en la metodología de la investigación es necesario para evitar anacronismos o presentismo. 


\section{DISERTACIONES}

ESTUDIOS

Para comprender mejor el contenido de las viñetas, este artículo se basa en la teoría del framing y protoperiodismo que utilizan David Varona et al. (2019, p. 739). Estos autores enumeran unos "mecanismos de persuasión" que deben estar en una narración periodística que intenta crear una imagen del "otro", lo que coincide con sensibilidades de la teoría queer y del fenómeno que se analiza en las viñetas, permitiendo su utilización en este caso así:

- Técnica de simplificación o enemigo único: la propaganda tiende a la simplicidad. Esta necesidad de precisar y resumir busca transmitir una idea única o eslogan, un único símbolo, e individualizar al adversario en un único enemigo.

- Técnica de exageración o desfiguración: se centra en resaltar cualquier información que le es favorable, utiliza citas fuera de su contexto y convierte cualquier hecho anecdótico desfavorable en una grave amenaza.

- Técnica de orquestación: [...] estas ideas deben presentarse incansablemente desde diferentes perspectivas - ya que la simple repetición aburriría pronto a la audiencia-, pero siempre insistiendo sobre el tema central.

- Técnica de transfusión: [...] la propaganda opera siempre a partir de un sustrato preexistente, ya sea una mitología nacional o un complejo de odios y prejuicios tradicionales. Se trata de difundir argumentos que puedan arraigar en actitudes primitivas.

- Técnica de la unanimidad y contagio: se centra en convencer a la masa de que esa idea es compartida por "todo el mundo" y se crea así una falsa ilusión de unanimidad. Otra técnica de contagio es reunir a diversos adversarios como un único individuo, una única categoría individualizada.

- Maniqueísmo: presentar al enemigo como una fuerza negativa, débil e, incluso, perversa para el bienestar social, mientras que las ideas que se defienden en la propaganda son necesarias, buenas y deben predominar para fortalecer a la comunidad.

Con el marco teórico y las técnicas vistas como guía, se procede a la elaboración de los campos semánticos resultantes y específicos en este caso. Como hipótesis se puede inferir que varias de las técnicas nombradas han sido utilizadas por los autores de las viñetas, apareciendo con especial relevancia la de simplificación, ya que es previsible que con este material gráfico y periodístico se buscara condensar la información y los estereotipos en imágenes impactantes y duraderas. De la misma manera, la exageración marcará la figura de Francisco con grandes cuernos, poses "afeminadas" muy marcadas, etcétera.

Es así como se definen unas preguntas de investigación que, guiadas por estos principios y el marco teóricometodológico, han de ser respondidas: ¿Cuál es la imagen que se da en la publicación de Los Borbones en pelota, de las masculinidades disidentes, concretamente, el caso del rey consorte Francisco de Asís? ¿Cómo es la relación entre esta publicación, la identidad de Francisco y los estereotipos perpetuados en los medios de comunicación posteriores? ¿Cómo se aborda en los medios de comunicación actuales este caso, resultado de los estereotipos transmitidos por esta publicación? Con las respuestas a estas preguntas se podrá conocer con más profundidad los mecanismos de exclusión utilizados hacia los sujetos LGTBQ en algunos contextos, en esta ocasión, en la comunicación decimonónica española y en su legado en la actualidad. 


\section{DISERTACIONES}

ESTUDIOS

\section{Resultados}

\section{Características de la presencia de Francisco en Los Borbones en pelota}

Poco después de la Revolución de 1868, Francisco coprotagonizó una de sus apariciones mediáticas más prolíficas: Los Borbones en pelota. La relevancia de esta publicación va más allá de su valor histórico, a nivel analítico es un testimonio de la percepción que se tuvo del rey consorte y que estuvo bastante extendida, sentando incluso, las bases de su imagen futura hasta nuestros días.

Esta obra no fue publicada conjuntamente sino hasta 1991 (Pageard et al.), aunque la edición más actualizada y completa es del 2012 (Burdiel) y circularon de manera dispersa en los años posteriores a 1868. Isabel Burdiel, biógrafa de Isabel II, reorganiza y contextualiza las viñetas como contenidos políticos y pornográficos, analizando la corporalidad de la reina y su representación como mujer en el movimiento liberal. Como objetivo se propone descubrir "un fenómeno de orden cultural y político decisivo: la fijación crítica en el cuerpo y la sexualidad de la reina para deslegitimar a la monarquía isabelina” (Burdiel, 2012, p. 15), al contrario de las publicaciones previas que se centraban en la estilística y la autoría. En la misma línea, resulta interesante y necesario designar la figura de Francisco de Asís de Borbón como protagonista de un análisis de estas viñetas, observando la fijación en su cuerpo como herramienta, no solo para deslegitimar a la monarquía isabelina, sino también a un sector de la población que comprende a los varones afeminados de clase alta. La autora explícita este objetivo en una serie de preguntas que, con tan solo cambiar el nombre de Isabel por el de su marido, resultan esclarecedoras sobre su potencial papel como protagonista:

¿Actuó la personalidad de [...] (Francisco) como caja de resonancia y caleidoscopio de las contradicciones de su época respecto a qué cosa debía ser la monarquía constitucional y qué cosa debían ser [...] (los hombres)? O, más exactamente, los discursos diversos en competencia sobre dos cuestiones aparentemente tan dispares - la institución monárquica y la feminidad (/masculinidad) - ¿se articularon en parte a través de las críticas (al rey como hombre) y a su actuación política como monarca? [...].

(Burdiel, 2012, p. 17)

En las siguientes líneas se analiza la presencia de Francisco en las viñetas, comentando respuestas a estas preguntas, pero, sobre todo, investigando la representación de su corporalidad y personalidad como sujeto de masculinidad disidente en complemento a lo estudiado por Burdiel, analizando cómo se llenó de significado la noción de "el otro" en este caso.

\section{El rey cornudo, pasivo y onanista}

El rey consorte es visible en 36 de las 102 imágenes expuestas por Isabel Burdiel -generalmente entendidas como la colección más completa-. Es este un número elevado, pero no excesivo, que hace justicia al papel del rey en la corte. De hecho, al analizar más en detalle su papel en las imágenes, se observa que protagoniza dos, quedándose en un papel secundario en las 34 restantes. En estas es subyugado a las actividades de su mujer o de otros personajes como el padre Claret o sor Patrocinio. La subordinación a las actividades de los demás no se debe a que fuese una fuente menor de "escándalos" sexuales, pero sí a lo que se entendió como una reducida relevancia política y un sesgo de preferencia hacia la frecuente actividad de la reina, por ser mujer y soberana. En esa 


\section{DISERTACIONES}

ESTUDIOS

línea se da prioridad a su papel de "cornudo", primer campo semántico de interés para esta investigación, que es interpretable en 20 de las 36 imágenes en las que aparece. Es una representación que liga a Francisco con una relación heterosexual, a la vez que ahonda en lo que los autores y su sociedad podrían entender como la pérdida de virilidad derivada de la actividad sexual con su mujer y su permisividad con ella. La siguiente copla, conservada en el Archivo de Maria Cristina, así lo confirma: "Un marido complaciente / yace en esta tumba fría / del mal afirma la gente / que nunca estuvo al corriente / de los hijos que tenía” (Burdiel, 2012, p. 87). Esta heterosexualidad prevalente protagoniza varias disertaciones teóricas en el campo de los estudios queer. Bernini, desarrollando los principios de Foucault, llega a la conclusión de que "la presión del sistema de clasificación sexo-género-identidad sexual [está relacionada con la] [...] violencia quirúrgica y jurídica” (2017, p. 92) ejercida sobre los cuerpos disidentes, a lo que se podría añadir - gracias al caso de estudio analizado en este artículo-, la violencia mediática. Ocurre que, como en los casos de intersexuales que nombra Bernini (2017) o que describen Cleminson y Vázquez García (2011), la heterosexualidad es preferida e incluso impuesta por los estamentos jurídicos, médicos y en este caso, mediáticos.

En seis viñetas se puede interpretar que Francisco de Asís está involucrado directamente en un acto sexual. Un análisis tradicional descartaría las escenas homosexuales como puramente simbólicas, por encontrarse en ellas el Padre Claret; sin embargo, una perspectiva queer enriquece la visión en este punto. Así, el rey se ve envuelto en diversas corporalidades, muchas de ellas ligadas a la pasividad, la recepción, la espera o el deseo no consumado. Estas, a su vez, elaboran los campos semánticos y núcleos de información en torno a los cuales se generan los estereotipos. En ocasiones, tiene sexo en rol pasivo, segundo campo determinante en su imagen. No lo hace solo como símbolo de la subyugación de la monarquía a los sectores conservadores de la iglesia, sino también a título personal. De este modo, aparece como un hombre percibido en su entorno por su masculinidad disidente, de no ser así, se habría escogido a la reina para tal papel, o se habría optado por otros modos de representación de dicha subyugación. El único compañero sexual masculino que a priori no pertenece a la iglesia es un pene anónimo, cuyo propietario se esconde tras un telón, podría ser un miembro del clero, pero también un amante perteneciente a las "bambalinas" del Estado, como lo era Meneses. De la misma manera, adopta roles más centrados en su estimulación genital y no anal, en los que, sin embargo, no alcanza a penetrar a otras personas como monjas o a Isabel, el "deseo no consumado" es el campo semántico rodeado por estas escenas. 


\section{ESTUDIOS}

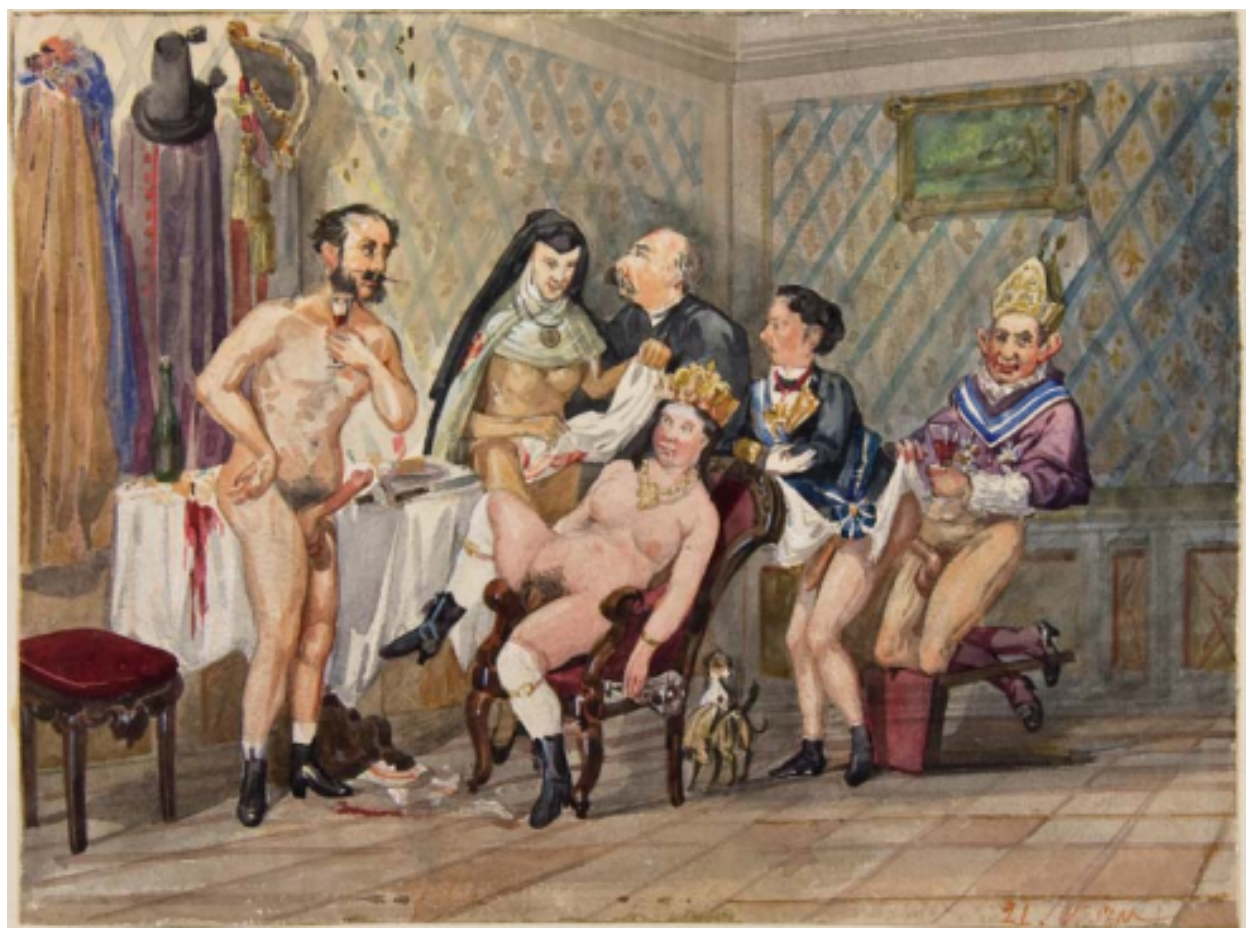

Figura 1. Sin título

Fuente: Burdiel (2012, p. 127).

El onanismo y el voyeurismo son las prácticas más frecuentes en el personaje, y el tercer campo de análisis, creando una imagen moralizante sobre los destinos que "esperan" a los maridos que "permiten" que sus mujeres sean sexualmente activas fuera del matrimonio. Esta es una "moraleja" propia de estampas y medios de comunicación del siglo xix en el ámbito internacional, como atestigua de manera mucho más conocida la viñeta sobre Kohada Koheiji realizada por Hokusai en $1831 .{ }^{2}$ Cruz Valenciano también describe con exhaustividad las expectativas establecidas por la sociedad burguesa decimonónica para maridos y esposas, entre las cuales, la castidad y la devoción al marido eran esperables, mientras que entre los hombres, el saber mantener su entorno familiar lejos de escándalos era una "virtud" necesaria (2014, pp. 54-64, 70-74). La viñeta 16(b) es un ejemplo de los muchos en este campo del "deseo no consumado", donde la Revolución irrumpe en el acto sexual que Francisco está observando entre Marfori e Isabel.

2 Véase en Museu Nacional D'Art de Catalunya. El fantasma Kohada Koheiji (Cien historias de fantasmas). https://www.museunacional.cat/es/colleccio/el-fantasma-kohada-koheiji-cien-historias-de-fantasmas/ katsushika-hokusai/005910-g 


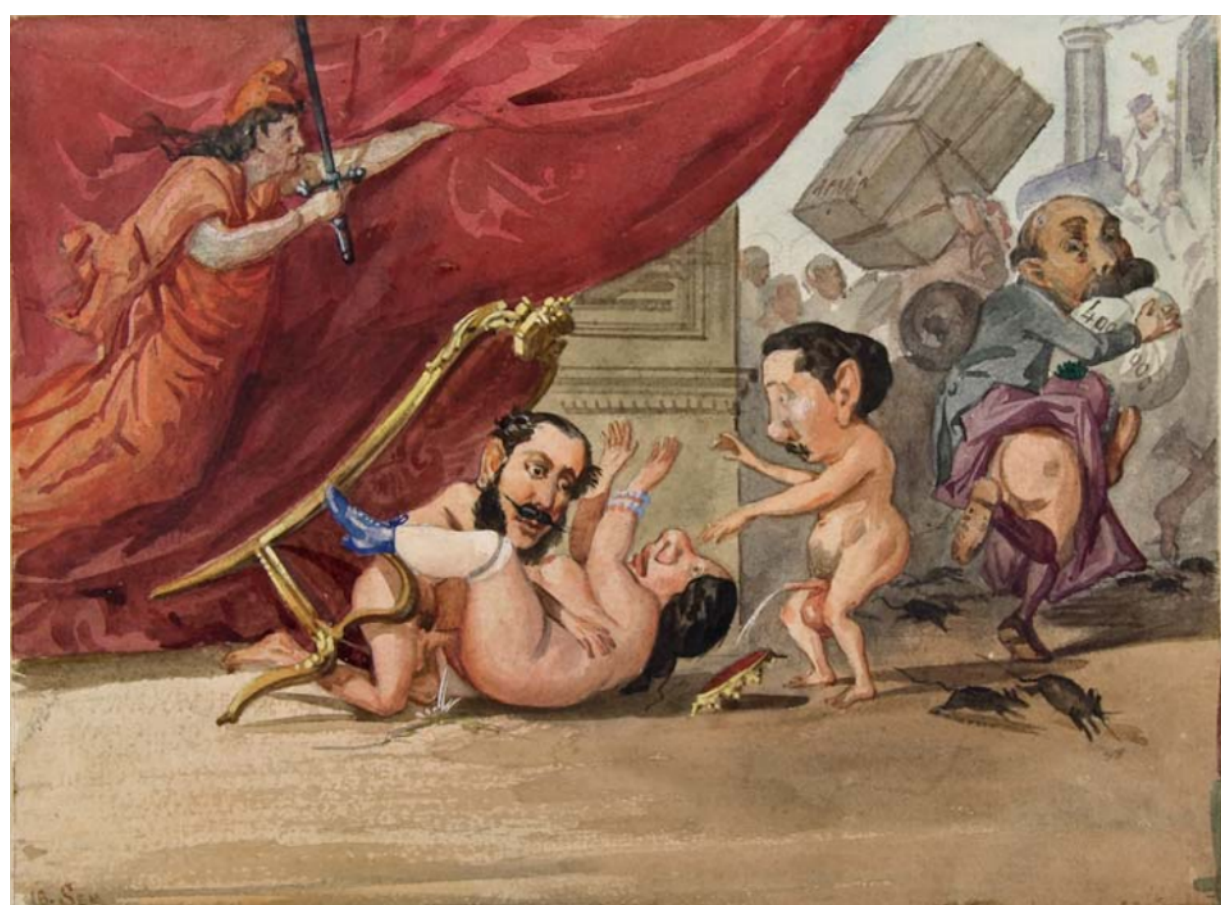

Figura 2. Sin título

Fuente: Burdiel (2012, p. 115).

Los tres campos mencionados son herramientas periodísticas que hacen parte de una estrategia de formación de estereotipos en la que ya aparecen las técnicas de Varona et al. (2019). La simplificación, al reducirse la personalidad del rey a tres elementos, es clara ya que se le presenta de manera casi exclusiva como "cornudo", pasivo y "pajillero". Además, estos roles se exageran, se orquestan y repiten de manera continua, mostrando cornamentas en gran número, tamaño y deformando los ademanes hasta el ridículo. Así mismo, se reconocen formatos preexistentes y propios de la transfusión, como son el odio a la monarquía, a la aristocracia y a un "vicio propio de la misma": la feminidad masculina. De ese modo, se reúne a otros adversarios en torno a estas ideas, como el padre Claret, Marfori y varios políticos contemporáneos. Por último, la intención de mostrar la debilidad del "otro" es palpable en escenas en las que la desnudez se utiliza como símbolo de pérdida del poder.

\section{Discusión}

\section{Francisco en su matrimonio}

Varias fuentes (correspondencia y documentos varios preservados en el Archivo Histórico Nacional, el Archivo General de Palacio, etc.) afirman que no existía una divergencia importante en cómo los medios de comunicación y la publicación que aquí se comenta, encasillaron a Francisco como un cornudo y, cómo él formó su propia identidad. El rey y su camarilla mostraron preocupación de diversas maneras, desde el inicio de la relación y 


\section{DISERTACIONES}

ESTUDIOS

prácticamente hasta su muerte, por la marca que impregnaba en su identidad el hecho de que su mujer intimase con otros hombres (Vidal Sales, 1995, p. 91). Uno de los momentos más esclarecedores al respecto, es la huida del rey al Pardo, poco después de casarse, y su negativa a retornar con su mujer hasta no tener la certeza de que no estaba embarazada, así como su insistencia en que el General Serrano dejara la capital (Rueda, 2014, p. 229); situaciones que causaron encontronazos con su mujer y con su suegra (Bruquetas de Castro, 2002, p. 323). El hecho de que en ocasiones el personaje parezca encontrarse más marcado por las relaciones de su mujer, que por las suyas, no solo es un testimonio de su papel como rey consorte, sino también, una fuente de información acerca de la moral decimonónica sobre la sexualidad y las jerarquías que esta ejercía en las diferentes "depravaciones", así como el papel que jugaba la mujer y su sexualidad.

En este sentido, el rey aparece a menudo como una persona conservadora que se preocupa por su imagen y la de la monarquía. Francisco y su legado estuvieron tan marcados por esta cuestión, que, de hecho, uno de los testimonios más directos sobre su sexualidad se encuentra en una carta que escribió a Benavides con motivo de las infidelidades de su esposa:

La presencia de un favorito nunca me hubiera sido desagradable si se hubieran guardado las formas.

No era necesario vejarme ¿comprendes? Es forzoso que Serrano desaparezca. Ha usado términos mal sonantes respecto a mí. Eso no lo admito. Serrano, ¿sabes lo que es? Un Godoy fracasado. El otro al menos, para obtener los favores de mi abuela, había sabido antes hacerse amar de Carlos iv. (Bruquetas de Castro, 2002, p. 324)

Respecto a lo teórico, esta distinción contribuye a la confirmación de la hipótesis de Mira, que hasta principios del siglo xx, la injuria (homofóbica) -sobre todo en los medios- tenía un contenido principalmente jocoso, que posteriormente se tornaría malicioso (Mira, 2004, p. 67). El modo en que se trata a Francisco en esta publicación es paradigmático en lo que concierne a la jocosidad sobre su masculinidad, mientras que se da más relevancia a la crítica de su "cornamenta". El periodo estudiado es interesante, entre otras cuestiones, por ser el de un tratamiento especial hacia la diversidad sexual y de género: la jocosidad y la heterogeneidad -tanto en su presencia como en sus características, dependiendo del medio de comunicación, del entorno económico-social del sujeto y de otros factores-. Son dos marcadores de que la sociedad decimonónica española se enfrentaba a un proceso de cambio. Esto se debe a las nuevas normas morales importadas por la burguesía y a los nuevos conceptos que empezaban a acuñar médicos y psicólogos. Las publicaciones comentadas concuerdan, por tanto, con los procesos descritos por Foucault:

La sodomía - la de los antiguos derechos civil y canónico- era un tipo de actos prohibidos; el autor no era más que un sujeto jurídico. El homosexual del siglo xix ha llegado a ser un personaje: un pasado, una historia y una infancia, un carácter, una forma de vida; asimismo una morfología, con una anatomía indiscreta y quizás misteriosa fisiología. Nada de lo que él es in toto escapa a su sexualidad [...]. La homosexualidad apareció como una de las figuras de la sexualidad cuando fue rebajada de la práctica de la sodomía a una suerte de androginia interior, de hermafroditismo del alma. El sodomita era un relapso, el homosexual es ahora una especie. (1977, pp. 56-57) 


\section{DISERTACIONES}

ESTUDIOS

Grupos minoritarios y estigmatizados: diversidad funcional, religiosa, étnica, afectivo-sexual o de identidad de género en la comunicación

ISSN: $1856-9536$

Doi: https://doi.org/10.12804/revistas.urosario.edu.co/disertaciones/a.10112 Volumen 15, Número 1 / Enero-junio 2022

Versión PDF para imprimir desde

A ello, Cleminson y Vázquez García añaden el "papel desempeñado por el discurso médico y psiquiátrico, viéndolo como el principal agente creador de la homosexualidad” (2011, p. 8) y Martínez el ideológico-social:

Por un lado, el pensamiento evoluciona desde el racionalismo ilustrado hacia el sentimentalismo romántico, que lleva aparejado un fortísimo sentimiento de la individualidad. De esta manera, no es extraño que una práctica que podía realizar cualquier individuo se acabe convirtiendo en un rasgo característico de su personalidad. Por otra parte, la sociedad había cambiado de forma muy significativa a lo largo del siglo xvill: la burguesía había alcanzado el poder gracias a diferentes revoluciones y sus preocupaciones e intereses eran diferentes a los de la aristocracia que lo habría detentado hasta entonces. (2020, pp. 171-172)

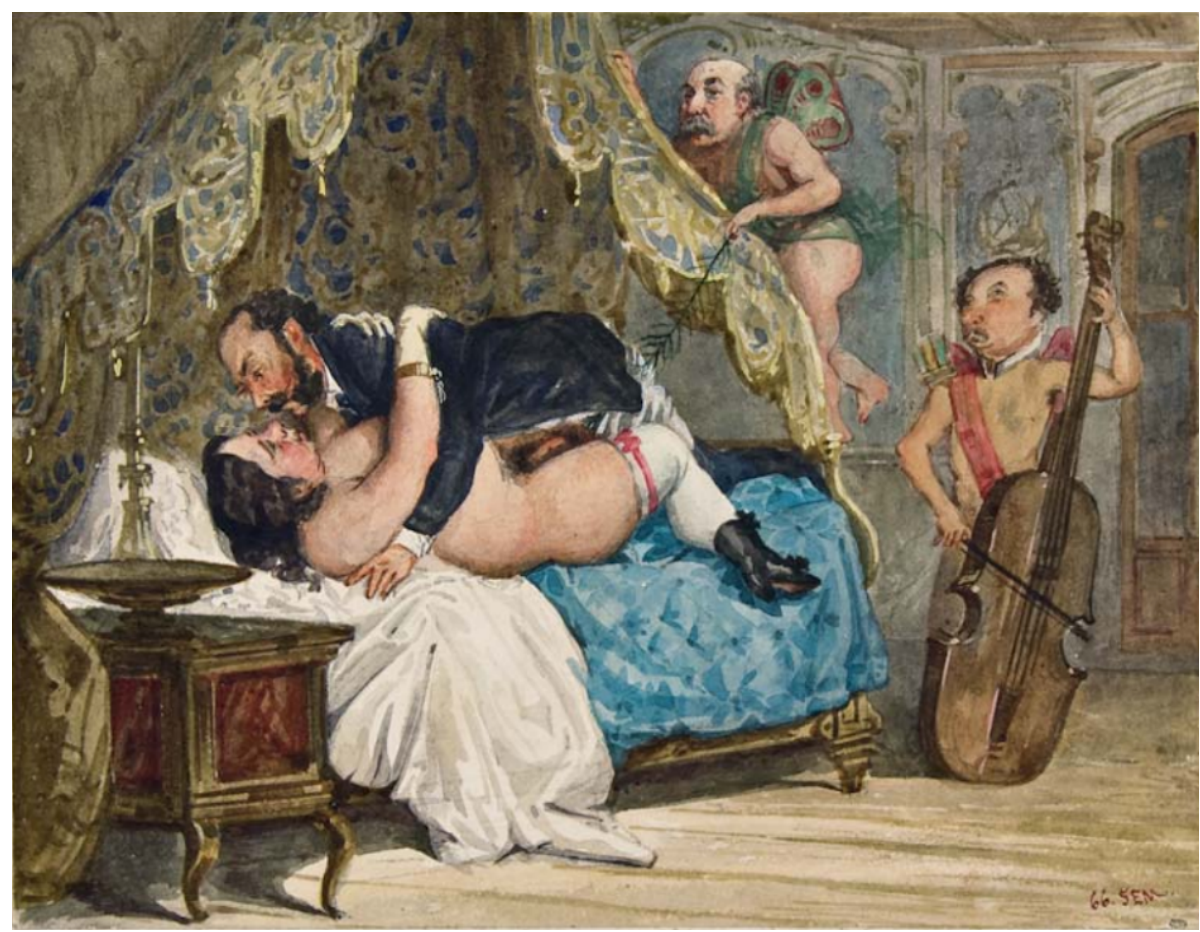

Figura 3. "Entre tanto el camastrón / cogido estaba al violón"

Fuente: Burdiel (2012, p. 197). 


\section{DISERTACIONES}

ESTUDIOS

Grupos minoritarios y estigmatizados: diversidad funcional, religiosa, étnica, afectivo-sexual o de identidad de género en la comunicación

ISSN: $1856-9536$

Doi: https://doi.org/10.12804/revistas.urosario.edu.co/disertaciones/a.10112

Volumen 15, Número 1 / Enero-junio 2022

Versión PDF para imprimir desde

La masculinidad de Francisco como objeto de mofa

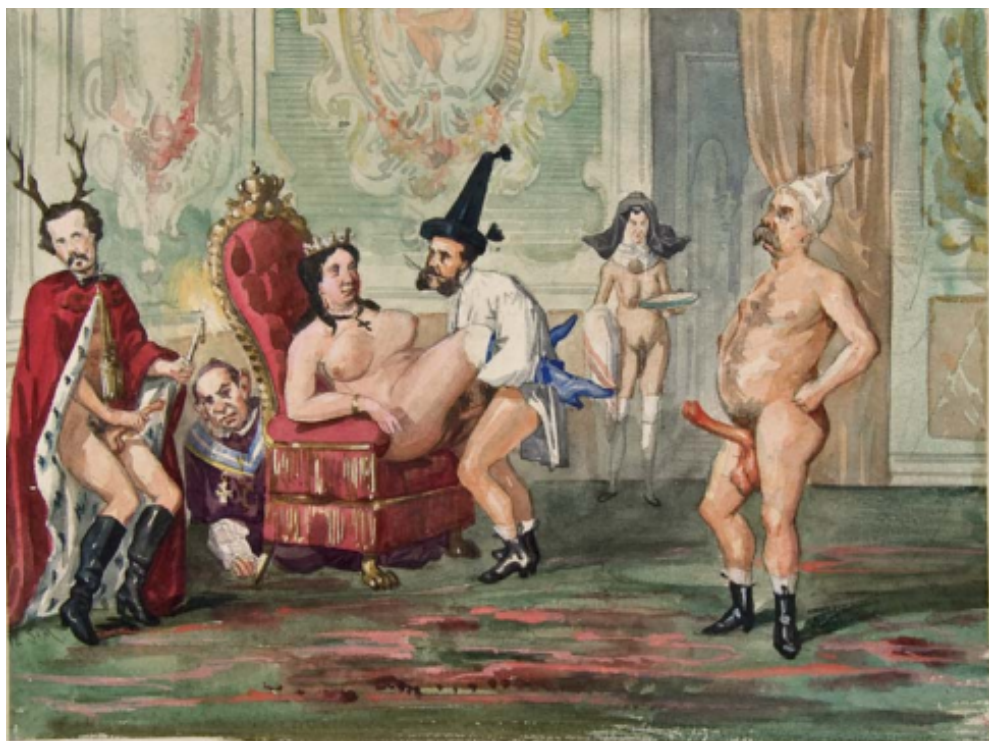

Figura 4. "Real taller de construcción de príncipes. Se admiten operarios"

Fuente: Burdiel (2012, p. 119).

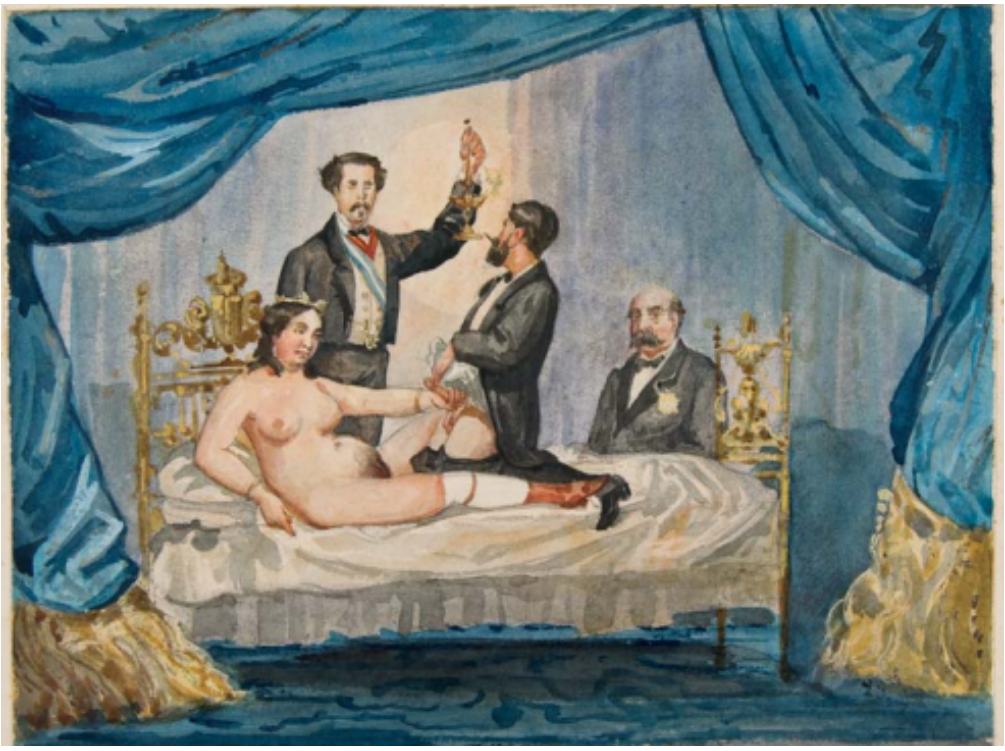

Figura 5. Sin título

Fuente: Burdiel (2012, p. 131). 


\section{DISERTACIONES}

ESTUDIOS

Grupos minoritarios y estigmatizados: diversidad funcional, religiosa, étnica, afectivo-sexual o de identidad de género en la comunicación

ISSN: $1856-9536$

Doi: https://doi.org/10.12804/revistas.urosario.edu.co/disertaciones/a.10112

Volumen 15, Número 1 / Enero-junio 2022

Versión PDF para imprimir desde

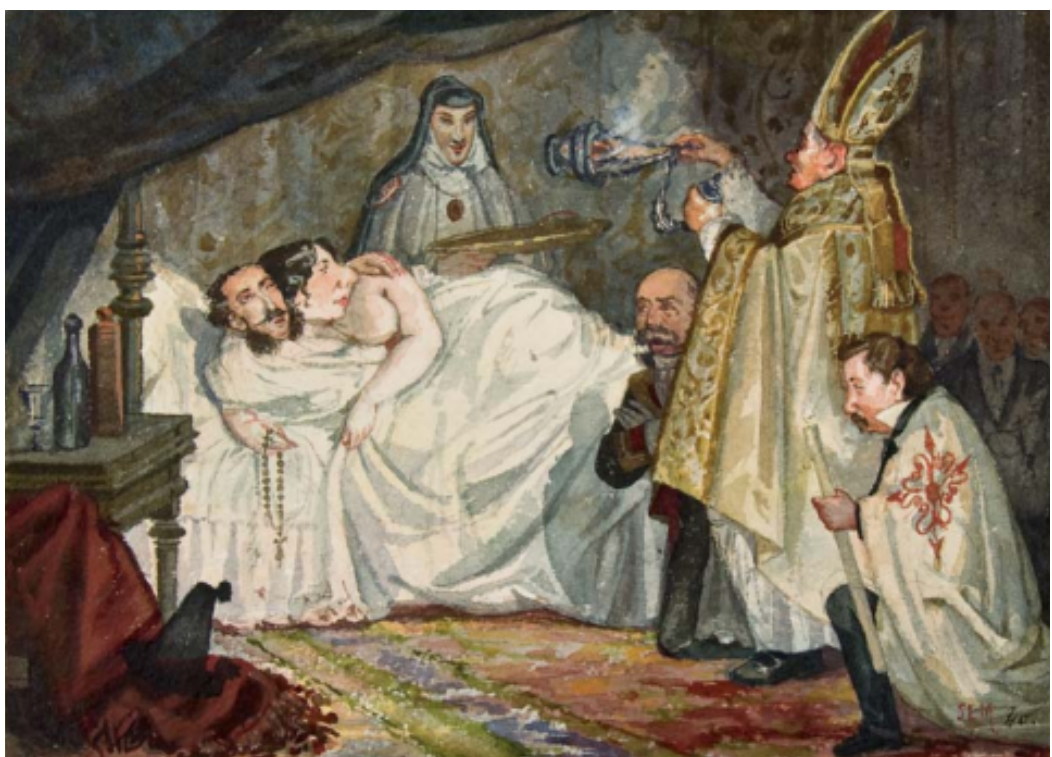

Figura 6. "Pío nono, agradecido / a los dones de Ysabel, / la da bula singularis / para que pueda joder" Fuente: Burdiel (2012, p. 157).

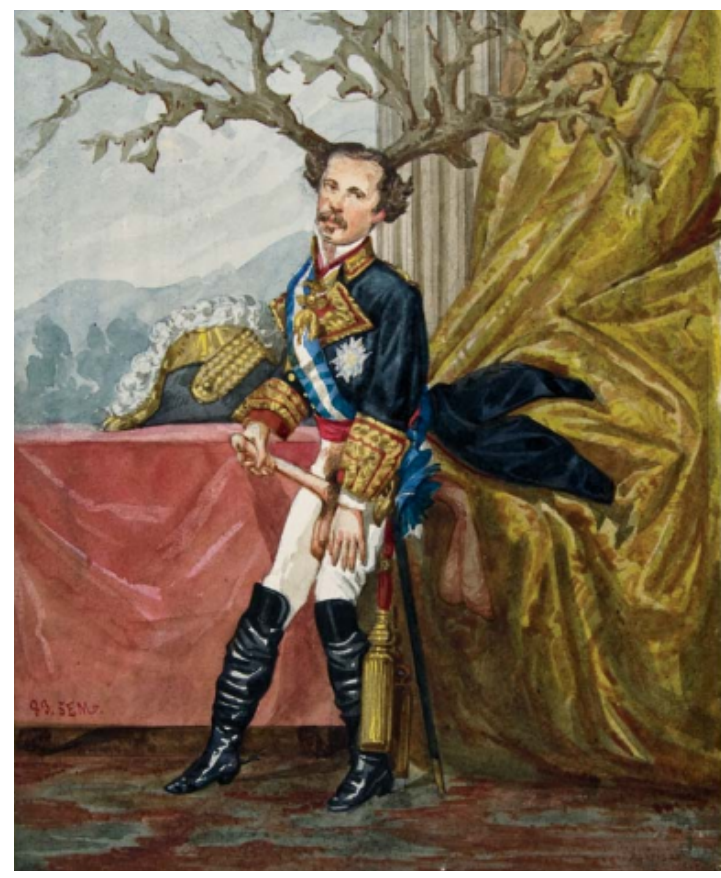

Figura 7. "El rey consorte / primer pajillero de la corte"

Fuente: Burdiel (2012, p. 225). 


\section{DISERTACIONES}

ESTUDIOS

A lo largo de la colección de viñetas, se percibe una insistencia en mostrar al rey como onanista y "sujetavelas". ${ }^{3}$ En la línea jocosa ya descrita, los varios instrumentos que toca (organillo, violonchelo, tambor, flauta y guitarra) simbolizan dichas condiciones, cuando no se le muestra directamente sujetando velas, candiles o masturbándose. En una de estas ocasiones, sin embargo, el tambor sugiere la aceptación de los hijos de Isabel como propios, en ese caso, Alfonso, aun sabiendo que no lo son. Esto conduce a otro tema clave en la identidad de Francisco y en sus apariciones en los medios: la descendencia. No existen pruebas, ni fuentes primarias que sugieran que alguno de los once bebés que Isabel ॥ dio a luz a lo largo de su vida fuera resultado de una relación sexual entre ambos cónyuges. Al contrario, la información existente apunta a una malformación congénita genital del marido, que tiende a complicar la fertilidad (Martínez, 2020, p. 179), a desavenencias en la pareja y falta de deseo, incompatibles con la actividad sexual frecuente, o incluso esporádica; a la presencia de otros candidatos a la paternidad más plausibles, al conocimiento de los hijos de sus paternidades biológicas, a las disimilitudes físicas entre Francisco y la descendencia real y, a una desconfianza de este hacia dicha descendencia. Todo esto no pasó desapercibido en lo que respecta a la identidad de Francisco, ni en los medios de comunicación, ni en su intimidad. Es por ello que aparece tocando el tambor mientras Alfonso baila, como si fuera un títere en la representación teatralizada de una paternidad no biológica que en el siglo xIx, era vista como inmoral:

Emilio Calderón se hace eco de los comentarios que aseguraban que la coyunda no se produjo durante la luna de miel ni en los meses siguientes por evidentes desarreglos sexuales del novio. [...] tras este comienzo teatral, en el que cada uno representaba su propio papel con más o menos profesionalidad, se mantuvo la relación un par de años, después se fue produciendo entre los dos cónyuges un ajuste, puramente formal y a prudente distancia que se mantuvo hasta el día en el que se dirigieron al exilio.

(Bruquetas de Castro, 2002, p. 322)

Este tono teatral es especialmente relevante en la identidad de Francisco por dos razones: de cara a los medios, la calidad y el carisma del "actor" se valoraron como "mediocres", la "función" se descubre desde un principio; y de cara a su intimidad, se veía constantemente frustrado por la necesidad de llevar una "doble vida" (Martínez, 2020, p. 179). Los medios y la cultura popular aprovecharon el descubrimiento de la feminidad del rey para extender coplas, un sistema de comunicación muy efectivo en la España decimonónica, utilizado en su gran mayoría para la mofa y el cotilleo:

Un cuartel, la redacción de un periódico, un banquete, una reunión familiar, un mitin político, una tertulia de amigos en un café o en un saloncillo de un teatro de la Corte: he aquí ambientes propicios para que se escuchen, entre risas, epigramas, letrillas, parodias, sonetos burlescos [...]. Al triunfo de una composición divertida contribuye también un recitado en voz alta, con gestos y ademanes que potencien su comicidad. (López Cruces, 2003, p. 1)

Fue por tanto una herramienta de comunicación muy útil al ser de fácil recordación, afín al carácter español y su concepción del humor. En el caso de Francisco, las coplillas representaron una combinación singularmente idónea con las viñetas, propiciando la creación en el imaginario colectivo del "bestiario" de Palacio, en el que los

3 En ocasiones, las viñetas muestran a Francisco literalmente sujetando velas, y otras veces, en posiciones que propician el acto sexual de Isabel con otros hombres. 
protagonistas eran la reina "ninfómana” y el rey femenino. En línea con lo que afirma López Cruces, se puede inferir que los ademanes que acompañan a la poesía humorística referente a Francisco, incluían la representación de lo que trasladaban las viñetas: gestos generalmente entendidos como femeninos, que en su concepción más simplista incluyen la agitación de las muñecas. Una forma de visualizar cómo imagen y sonido se fundían para formar una identidad en la masculinidad disidente cuando alguien recitaba una de estas coplillas, era leer la siguiente:

\section{¿Quién no conoce al pinche de cocina [Marfori] / y al fraile salteador [M. Claret] / y al pobre ratoncillo de ofi- cina [Meneses] / y al femenil señor? [Francisco de Asís] / ¿Quién no conoce a la monja lacia [S. Patrocinio] / y el torpe frenesí? / ¿Y quién, Isabelita, por desgracia / no te conoce a ti? (Burdiel, 2012, p. 87)}

En esta copla cada personaje tiene una representación con carga gráfica, lo que permite la asignación de ademanes, y por ende, la creación de imágenes más perdurables en el público. No es, sin embargo, la única que alude a la masculinidad disidente de Francisco: "Paco natillas es de pasta flora / que se mea en cuclillas como una señora" (Vidal Sales, 1995, p. 65). "El rey don Paco natillas / misterio insondable es / alterna nabo y mantillas / adivina tú lo que es" (Vidal Sales, 1995, p. 129). “Isabelona, tan frescachona / y don Paquito, tan mariquito" (Martínez, 2020, p. 180). Y una de las más conocidas: "Gran problema es en la Corte / averiguar si el Consorte / cuando acude al escusado / mea de pie o mea sentado” (Martínez, 2020, p. 180). Incluso, se podría decir que “icon Paquito no!”, la exclamación acuñada a Isabel en la noche de bodas, significó más una chanza o chascarrillo popular que un hecho verificable y concreto.

Estas teatralizaciones, unidas al poder comunicativo de los materiales gráficos frente a los escritos, contribuyen a la tercera de las técnicas descritas por Varona et al. (2019), que en gran medida, permiten y alientan la repetición de las ideas hasta que estas se convierten en parte del imaginario colectivo. Además, son favorables en mayor medida que el texto escrito a la exageración. Las propias viñetas reconocen la efectividad de su mensaje, y cómo este, a través de los canales de comunicación que establece, tiene la posibilidad de perpetuarse:

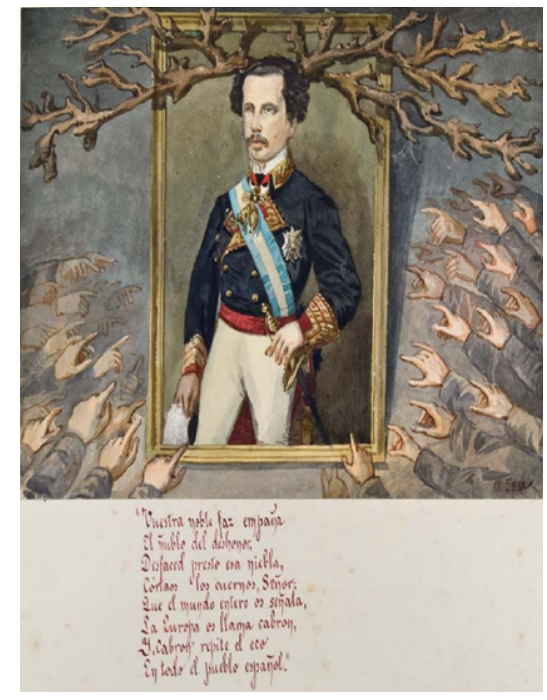

Figura 8. "Vuestra noble faz empaña [...]"

Fuente: Burdiel (2012, p. 207). 


\section{DISERTACIONES}

"Vuestra noble faz empaña / El ñublo del deshonor / Desfaced presto esa niebla/ Cortaos los cuernos, Señor: / Que el mundo entero os señala/ La Europa os llama cabron/Y "cabron" repite el eco/ En todo el pueblo español” (Lámina 17) (Caballero-Espericueta, 2019, p. 146). Así, se alude al grado de conocimiento percibido que tenía el pueblo español sobre el papel del rey en los "escándalos" del palacio, y además, se le interpela a él directamente, esperando que estos mensajes tengan un efecto en su comportamiento. También se ofrece un ejemplo paradigmático de las técnicas de unanimidad y contagio, hablando de que Europa y todo el pueblo español comparten el mensaje de la copla.

Es por esto que resulta interesante recordar que algunas de estas coplas y viñetas han sido encontradas en los documentos de María Cristina, lo cual es prueba de que sus mensajes llegaban a oídos de la corte, e incluso, del propio Francisco. Durante toda su vida se mostró preocupado por su reputación y la de su familia, consciente de que existían habladurías al respecto de su masculinidad, y de que muchos ciudadanos lo encontraban gracioso. En 1874, ya en el exilio, escribe una carta a su hermana desde París, en la que se mostraba consciente de que muchos se "burlaban de [sus] [...] palabras, [aunque] el tiempo ha venido a cambiar aquellas risas y mofas en llantos y sollozos" (De Asís, 1874). Años atrás ya intercambiaba varias cartas que giraban en torno a la importancia de mantener una reputación y, no despertar malos comentarios en los demás; en 1845, por ejemplo, aconseja a su hermano "que no se junte con personas que den mal nombre a la familia" (De Asís, 21 de febrero de 1845). Estos y otros pensamientos transmitidos por Francisco en sus escritos, reflejan la visión de su matrimonio como una oportunidad para mejorar su reputación o el posterior miedo a que este la arruinase, y hacen pensar que las publicaciones y comentarios resultantes, interactuaron con su identidad.

\section{La imagen de Francisco más allá de Los Borbones en pelota}

Las viñetas de los hermanos Bécquer, publicaciones similares en postales y periódicos de la época, sus ecos en la cultura popular y la relación que tienen con la identidad de Francisco, reflejan los desarrollos en la cultura burguesa decimonónica y su visión de la familia, la realeza, la sexualidad y otros valores sociales que sientan las bases de nuestras categorías actuales:

Tras los trabajos pioneros de David Cannadine y Benedict Anderson, hemos asistido en los últimos años a una interesante proliferación de estudios sobre las características particulares y las formas posibles de representación monárquica de los diversos imaginarios nacionalistas y, en menor medida quizás, sobre los valores asociados a la monarquía como encarnación simbólica de la nueva sociedad burguesa. Un entramado de nuevos (o reformulados) valores culturales cohesivos, tanto horizontales como verticales, capaces de legitimar (o no) los particulares mecanismos de inclusión y exclusión de los nuevos regímenes liberales y monárquicos. (Burdiel, 2012, p. 18)

La forma en que Francisco se mostraba preocupado por la situación de su familia, su posición social y los escándalos que podían aparecer por el comportamiento de su hermano, o de su mujer, revela que, en el fondo, estaba embebido por los nuevos valores culturales de los que hablan Burdiel, Cannadine, Anderson y otros autores como Cruz Valenciano (2014). Es posible que, en línea con estos valores, le preocupara bastante la imagen que los españoles tenían de su masculinidad y cómo esta entroncaba con su posición de rey consorte. Como se ha constatado en el análisis previo, los medios no eran ajenos a dicho binomio, lo que derivaba en multitud de producciones audiovisuales y en una imagen que ha permanecido hasta nuestros días: la del rey afeminado. 


\section{DISERTACIONES}

En efecto, los medios de comunicación no han olvidado la imagen decimonónica de Francisco; ni las fuentes periodísticas, ni las académicas se han esforzado por alejarse de una imagen superficial y estereotipada. En la actualidad, decir Francisco de Asís, en cualquier contexto, ya sea en una clase de la Eso, una biografía de Isabel ॥ 0 un artículo periodístico sobre la homosexualidad en los Borbones, implica nombrar tres asuntos clave. El primero y omnipresente es el "suceso de las puntillas", 4 el segundo suele hacer referencia a las hipospadias ${ }^{5}$ o a la voz "atiplada", como representantes de una feminidad. Y en el tercero, es posible que aparezca el nombre de Antonio Ramos de Meneses, seguido de afirmaciones dispares y nunca argumentadas con fuentes primarias que van desde la relación profesional (el secretario) hasta el amor, pasando por la amistad. Las afirmaciones e ideas que se mantienen en la divulgación actual funcionan con los mismos campos semánticos que utilizaban las viñetas, estos además, son visibles tanto en la investigación formal como en la actividad puramente periodística. Han sido objeto de deformación, no obstante, de modo que el campo de la feminidad/pasividad (las "puntillas", la voz "atiplada") y el de "cornudo", se han reforzado y llenado de nuevos significados, que tienden a subrayar su papel "secundario" en la historia personal y política frente a su esposa, la cuestión del onanismo ha perdido fuelle frente a la revitalización de la "medicalización”, un proceso que ya existía en el siglo xIx, y que sigue presente al día de hoy en lo que concierne a la ya nombrada cuestión de las hipospadias.

A pesar de la creciente importancia de la investigación y las sensibilidades queer, varios informes constatan el papel secundario al que se somete esta perspectiva en la historiografía actual (Andrews et al., 2020). La historia de Francisco y los tópicos a los que se ha hecho referencia previamente, son prueba de dicho desinterés. Es inusual que, tratándose de un rey europeo del siglo xix, tan solo se le haya dedicado una biografía novelada en 1995, algunos artículos periodísticos y párrafos en biografías de su esposa. Existe un desconocimiento generalizado en lo que respecta a su vida e identidad y, ese es el principal legado que marca el tratamiento que se realiza de su figura en los medios actuales.

Bárbara Rosillo, en un artículo del 20 de abril del 2019 titulado “¡Por Dios Paco, si llevas más puntillas que yo!”, proporciona un ejemplo de las asunciones expuestas como herencia del siglo xIx. Las referencias a la noche de bodas en este texto hablan de una consumación "sin pena ni gloria" (Rosillo, 2019) y después de asegurar que Francisco mantuvo relaciones heterosexuales con Isabel II, se lee: "Se ha hablado de la supuesta homosexualidad de Francisco de Asís, popularmente conocido como 'Paquita'. A juzgar por el citado episodio, tal vez, fuera algo amanerado, aunque es bien sabido que tuvo varias amantes y uno que otro hijo ilegítimo" (Rosillo, 2019).

La historiadora de la Universidad de Sevilla no resuelve la contradicción en la que ya caían las viñetas al seguir apelando a una posible homosexualidad para inmediatamente atribuir a Francisco conductas heterosexuales. En este caso, incluso asegura que es bien sabido que tuvo varias amantes y algún hijo (Rosillo, 2019), cuando no se conocen fuentes primarias que así lo avalen y las secundarias se reducen a la biografía de Narváez de Jesús Pabón (1983). Ramón Martínez protagoniza el ejemplo más reciente de la tendencia a mantener los campos popularizados por los hermanos Bécquer y de las tiranteces que estos producen cuando se cruzan con la idiosincrasia

4 Es famoso el episodio en el que en la noche de bodas, Isabel Il exclamó, presuntamente: "¡Por Dios Paco, si llevas más puntillas que yo!".

5 "En los casos de hipospadias, la abertura de la uretra se encuentra en la parte inferior del pene, en lugar de la punta" (Mayo Clinic, 2018). 


\section{DISERTACIONES}

académica y mediática del siglo xx. En el 2020 este autor publicó Maricones de antaño: historias LGTB de la Historia, en el cual dedica parte de un capítulo al rey consorte y, como en ocasiones anteriores, gira en torno a "Con Paquita no", "el suceso de las puntillas" y las hipospadias. A pesar de exponer de nuevo estas ideas, el autor incluye ciertas novedades que añaden algo de contexto a la breve reseña biográfica. Afirma Martínez que, "aún quedan muchas investigaciones por hacer, y es preciso profundizar mucho más en los pocos datos que conocemos" (2020, p. 181), siendo esta última una realidad plasmada en la carencia de fuentes de esta y otras publicaciones similares. Destacan, sin embargo, por ser únicas en esta serie de ejemplos, la contextualización sobre la sexualidad en el siglo xix europeo y español (Martínez, 2020, pp. 171-181) y las hipótesis sobre la relación con Antonio Ramos Meneses que, a pesar de moverse entre lo laboral y lo romántico, sí que clarifica puntos importantes, como la extensión y estabilidad en el tiempo y la concesión del título de Duque de Baños como datos clave para su interpretación.

Así mismo se menciona la cuestión de la paternidad de los hijos de Isabel ॥ y de su promiscuidad, aunque no queda claro si el autor considera que alguno de los hijos reales fue fruto de relaciones sexuales entre los consortes y parece achacar el número de amantes de Isabel a la sexualidad de su marido. Respecto al matrimonio, también cabe destacar la interpretación que realiza de este como un hecho "triste, porque desvela las muchas desgracias que algunas personas tuvieron que soportar para mantener su estatus, renunciando a todo afecto que fuera de su agrado" (Martínez, 2020, p. 179). Otros autores como Eusebio Ferrer Hortet y María Teresa Puga García (1993) coinciden en este diagnóstico, llegando sus investigaciones a la conclusión de que este casamiento fue causa de infelicidad, especialmente en la reina. Las fuentes primarias apuntan a que Francisco deseó esta unión antes de que se produjese, y actuó en su favor, reclamando incluso un crédito en París para su "campaña" personal (Vidal Sales, 1995, p. 27; Rico Góngora, 2017, p. 30). Los sentimientos de Isabel al respecto, no parecían ser tan favorables, sin embargo, al contrario de lo que piensan los medios contemporáneos y algunos de los ejemplos más recientes, no es una certeza que de haberse casado con un hombre más de su agrado, como Leopoldo de Coburgo (Burdiel, 2010, p. 171), hubiese sido más feliz. Las fuentes afirman que Isabel no era favorable a la monogamia (Burdiel, 2010, p. 171) y un marido menos permisivo que Francisco en este respecto, habría fomentado el conflicto.

Burdiel continúa en su libro con las líneas en las que se desarrolla esta argumentación. Aparecen en esta biografía los tópicos de la "voz atiplada", las hipospadias, las "puntillas" y no se entra en el análisis sobre la relación de Francisco con Antonio. Al ser una biografía de la reina, es explicable la falta de profundización en la vida del marido; sin embargo, un grado de investigación que permitiese discernir el tipo de relación extramatrimonial que tenía, sí habría sido pertinente. Al igual que Eusebio Ferrer Hortet, María Teresa y Ramón Martínez, considera que el matrimonio fue un fracaso y titula el cuarto capítulo "Aquel desacierto insigne". A lo largo de ese capítulo da a entender, entre otras cosas, que Francisco y su sexualidad tuvieron responsabilidades en su condición de cornudo y contribuye a la reformulación del primero y más relevante de los tres campos estudiados en este artículo, que no permite salir de la caracterización del rey como un "otro".

Finalmente, además de los casos de divulgación académica enumerados, se ha de recordar que los medios de comunicación enfocados al público general también se suman a los campos previamente descritos. XL Semanal (2020) y Vanity Fair (2020) han publicado recientemente artículos sobre la corte isabelina que mantienen los debates sobre las infidelidades y la feminidad en la pareja real, que se suman a estas tendencias. 


\section{DISERTACIONES}

ESTUDIOS

\section{Conclusión}

Al observar estos comportamientos en investigadores y en los medios que se encargan de difundir sus mensajes, es claro que existen voluntades cruzadas en lo que respecta a los personajes históricos con sexualidades o géneros disidentes: por un lado, se intenta apelar a sus condiciones con afán sensacionalista, mientras que las pulsiones heterosexistas intrínsecas a la academia y a los medios luchan contra esta tendencia; por otro lado, ambas condiciones contribuyen a la perpetuación de vacíos en el conocimiento histórico.

Las viñetas muestran una forma de tratar las masculinidades disidentes estrechamente ligada con la formación de estas identidades, como marcadora de estereotipos y contradicciones. En este caso, tendían a priorizar el papel de marido heterosexual de Francisco de Asís frente a su masculinidad disidente, pero sin olvidarla, lo que posiblemente ha derivado en las contradicciones ya descritas. Es paradigmático cómo una de las pocas que le muestra en actividad sexual con otro hombre, decide no mostrar el rostro de su compañero, en un acto metafórico del desconocimiento que se tiene sobre la posible relación que mantuvo con Antonio Ramos Meneses. Por último, cabe destacar que el rey es presentado como onanista y "sujetavelas", papeles propios de la "marioneta", que muchos opinan se convirtió desde que tomó la decisión de casarse con su prima y a lo largo de toda su actividad como padre de familia. Se puede afirmar que la imagen que se da de Francisco en los medios de comunicación, especialmente en Los Borbones en pelota se basa en tres encuadres: "cornudo", "pasivo/afeminado" y "onanista/ enfermo". Además, esta imagen está estrechamente relacionada con su identidad, muy marcada por la preocupación acerca de su reputación y la de su familia. Finalmente, aunque reformulada y cargada de nuevos significados, esta imagen mantiene sus campos semánticos en los medios actuales.

\section{Referencias}

1. Andrews, F., Catterall, P., Evans, I., Finn, M., Foxhall, K., Green, A., Harris, O.A., Pendleton, A., Gust, O., \& Spicer, A. (2020). LGBT+ Histories and Historians Report Royal Historical Society. The Royal Historical Society. https:// files.royalhistsoc.org/wp-content/uploads/2020/09/25175110/RHS_LGBT_Report_ACCESSIBLE.pdf

2. Baciero, C. A. (2020). Isabel ॥ de España, la reina que tuvo 12 hijos sin consumar su matrimonio. Vanity Fair. https://www.revistavanityfair.es/realeza/articulos/reina-isabel-ii-espana-francisco-asis-borbon/47105

3. Bernini, L. (2017). Las teorías Queer. Egales.

4. Boos de Quadros, C. M., Durieux Zucco, F., Foletto Fiuza, T., \& De Souza Farias, F. (2021). Fuentes de información, credibilidad y publicidad: perspectivas para el desarrollo de la comunicación regional. Anuario Electrónico de Estudios en Comunicación Social "Disertaciones", 14(1), 1-20. https://doi.org/10.12804/revistas. urosario.edu.co/disertaciones/a.9003

5. Bruquetas de Castro, F. (2002). Los reyes que amaron como reinas. La esfera de los libros, S.L.

6. Burdiel, I. (2010). Isabel II. Una biografía (1830-1904). Taurus.

7. Burdiel, I. (2012). Los Borbones en pelota. Institución Fernando el católico. https://ifc.dpz.es/recursos/ publicaciones/32/48/_ebook.pdf 


\section{DISERTACIONES}

ESTUDIOS

8. Caballero-Espericueta, M. (2019). Pornografía y sedición: la propaganda antimonárquica hacia 1868. Historia Digital, 19(33), 133-146. https://dialnet.unirioja.es/servlet/articulo?codigo=6771007

9. Cleminson, R., \& Vázquez García, F. (2011). Los invisibles: Una historia de la homosexualidad masculina en España, 1850-1939. Comares.

10. Cruz Valenciano, J. (2014). El surgimiento de la cultura burguesa. Siglo xxı Editores.

11. De Borbón, F. (1874). [Carta a su hermana]. Títulos y Familias (3784, leg. 48), Archivo de Palacio Real.

12. De Borbón, F. (1845, 21 de febrero). [Cartas a su hermana]. Fondo de Isabel Fernanda de Borbón y Borbón y Dos Sicilias; Archivo Histórico Nacional.

13. Fernández Jiménez, A. (2021). El romance periodístico de Jaime Campmany como modelo de periodismo literario en la España de finales del siglo xx. Anuario Electrónico de Estudios en Comunicación Social "Disertaciones", 14(1), 1-22. https://doi.org/10.12804/revistas.urosario.edu.co/disertaciones/a.8462

14. Ferrer Hortet, E., \& Puga García, M.T. (1993). Se busca Rey consorte. La historia de Isabel II de 1830 a 1904. Planeta.

15. Foucault, M. (1977). Historia de la sexualidad: 1-La voluntad del saber. Siglo xxı Editores. https://seminariolecturasfeministas.files.wordpress.com/2012/01/foucault_michel-historia_de_la_sexualidad_i_la_ voluntad_de_saber.pdf

16. López Cruces, A. J. (2003). Poesías jocosas, humorísticas y festivas del siglo xix. Alcorde Ediciones. http:// www.cervantesvirtual.com/obra-visor/poesias-jocosas-humoristicas-y-festivas-del-siglo-xix--0/html/ ff1bb3ee-82b1-11df-acc7-002185ce6064_12.html

17. Martínez, R. (2020). Maricones de antaño: Historias LGtв de la Historia. Egales.

18. Mayo Clinic. (2018). Hipospadias. Mayo Clinic. https://www.mayoclinic.org/es-es/diseases-conditions/hypospadias/symptoms-causes/syc-20355148\#: :text=El\%20hipospadias\%20es\%20un\%20defecto,vejiga\%20 y\%20sale\%20del\%20cuerpo

19. Mira, A. (2004). De Sodoma a Chueca. Egales.

20. Pageard, R., Fontanella, L., \& Cabrera, M. D. (1991). Los Borbones en pelota. El Museo Universal.

21. Pabón, J. (1983). Narváez y su época. Espasa-Calpe.

22. Pérez-Reverte, A. (2020). Los Borbones vistos por Arturo Pérez-Reverte en 'Una historia de España'. xL Semanal. https://www.xlsemanal.com/actualidad/20200805/vida-borbones-monarquia-exilio-reverte-historia-de-espana.html

23. Répide, P. (1932). Isabel II: Reina de España. Espasa.

24. Rico Góngora, M. (2017). Monarquía, Historia de España, Isabel II y Francisco de Asís la extraña pareja Clío. Revista de historia, (189), 24-31. https://dialnet.unirioja.es/servlet/articulo?codigo=6044524

25. Rosillo, B. (2019, 20 de abril). ¡Por Dios Paco, si llevas más puntillas que yo!. Blog personal. https://barbararosillo.com/2019/04/20/6179/

26. Rueda, G. (2014). La nobleza española, 1780-1930. Ediciones RH.

27. Varona Aramburu, D., Pérez-Escolar, M., \& Sánchez Muñoz, G. (2019). Teoría del framing y protoperiodismo. Estudio de los atributos asociados a la figura de Magallanes en los diarios de Pigafetta y Francisco Albo. Revista Latina de Comunicación Social, 74(5), 734-747. https://doi.org/10.4185/RLCS-2019-1354 


\section{DISERTACIONES}

\section{ESTUDIOS}

28. Vázquez García, F. (2001). El discurso médico y la invención del homosexual. Asclepio, 53(2), 143-161. http://asclepio.revistas.csic.es/index.php/asclepio/article/view/163

29. Vidal Sales, J. A. (1995). Francisco de Asís de Borbón y Borbón. Planeta.

30. Zubiaurre, M. (2014). Culturas del erotismo en España, 1898-1939. Cátedra. 